\title{
THE HEAT COAGULATION OF MILK
}

BY

H. H. SOMMER AND E. B. HART

\section{UNIVEROTY OT WISCONSIN}

\section{PH. D. THESIS_ 1922}

(From the Department of Agricultural Chemistry, University of Wisconsin, Madison) 



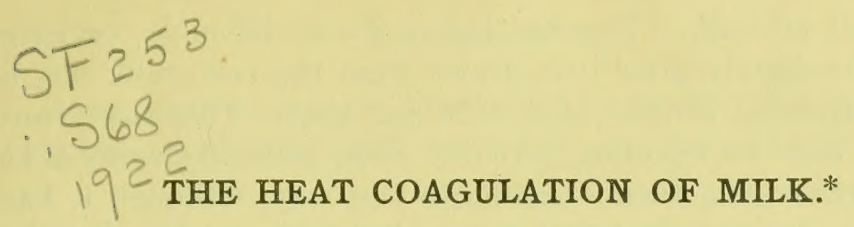

BY H. H. SOMMER AND E. B. HART.

(From the Department of Agricultural Chemistry, University of Wisconsin, Madison.)

(Received for publication, September 17, 1919.)

The coagulation of milk by heat was first observed by Hammersten, ${ }^{1}$ who found that it occurred at from $130-150^{\circ} \mathrm{C}$. with different samples of milk. Since then the question has been studied very little, and no tenable explanation has ever been given for the difference in the coagulating points of milks from different cows. In recent years a knowledge of the factors which determine this difference has become very desirable, for these same factors undoubtedly determine whether a condensed milk will coagulate when it is sterilized. The coagulation of condensed milk on sterilizing causes serious losses in the milk-condensing industry.

In the manufacture of condensed milk, the fresh milk is first pasteurized or "preheated" at from $180-210^{\circ} \mathrm{F}$. for from 1 to 20 minutes. The condensing is done under vacuum at $130-160^{\circ} \mathrm{F}$. After the desired concentration has been attained, the milk is put into cans, sealed, and then sterilized at $224-240^{\circ} \mathrm{F}$. for 20 to 50 minutes. It is during the sterilizing process that the coagulation occurs. Because it occurs so frequently, all the condensed milk is placed into shaking machines to break up any loose coagulum that may have formed. However, frequently the coagulum is so firm that even after shaking the milk remains lumpy. Such a product is rejected by the consuming public, and thus is a loss.

Manufacturers have sought to solve the problem by controlling the acidity of the milk. They have set an arbitrary standard such as 0.18 per cent acid (calculated as lactic acid), above which

* Published with the permission of the Director of the Wisconsin Agricultural Experiment Station.

${ }^{1}$ Quoted from l terature referred to in, Kastle, J. H., Chemistry of milk, Hyg. Lab., Bull. 56, 1909. 
they reject all milk. This has led to much difficulty, because often, immediately after it is drawn from the cow, milk has a higher titratable acidity than 0.18 per cent. Thus the condenseries may be rejecting perfectly fresh milk, believing that they are remedying their difficulty in this way, although it has never been demonstrated that titratable acidity is related to the coagulation. The factors involved in the coagulation have never been determined, and no explanation is available on which to base a remedy for this difficulty.

To offer an explanation for the difference in the coagulating points of different milk samples the following factors were studied: titratable acidity, hydrogen ion concentration, concentration of the milk, and composition and balance of the milk salts.

\section{The Heat Test.}

The temperature at which the milk was heated was arbitrarily set at $136^{\circ} \mathrm{C}$. At first the heating was done in an autoclave at 50 pounds pressure for 20 minutes, and in that way the milks were differentiated into coagulating and non-coagulating. With the autoclave, it took about 10 minutes to get up to the desired pressure; and, after the milk had been heated, the pressure had to be released gradually to prevent the milk from boiling over. The disadvantages of this method were such that there were no sharp limits from which to calculate the 20 minute interval, and it was impossible to determine the relative rates at which the milk samples coagulated.

To overcome these disadvantages the milk was placed into small glass tubes, sealed, and then heated in a xylene vapor bath which was constant at $136^{\circ} \mathrm{C}$. within $0.5^{\circ} \mathrm{C}$. The sealed tubes were clamped in a rack, só arranged that it could be tilted to invert the tubes, to see how the milk would flow, and in that way it was possible to determine the exact length of time required for each sample to coagulate. The milk in the sealed tubes was up to $136^{\circ} \mathrm{C}$. in less than 1 minute, so the point from which to calculate. the time was practically the instant the tubes were inserted intothe vapor bath.

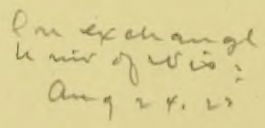




\section{H. H. Sommer and E. B. Hart}

\section{Titratable Acidity.}

Since condenseries are attempting to remedy the coagulation problem by rejecting milk above 0.18 per cent acid (calculated as

TABLE I.

Titratable Acidity and Coagulation.

\begin{tabular}{|c|c|c|c|c|c|c|c|c|}
\hline \multicolumn{3}{|c|}{ May 8, 1919.} & \multicolumn{3}{|c|}{ May $10,1919}$. & \multicolumn{3}{|c|}{ May 16, 1919.} \\
\hline \multirow[t]{2}{*}{ Cow No. } & $\begin{array}{l}\text { Titratable } \\
\text { acidity. }\end{array}$ & $\begin{array}{l}\text { Coagu- } \\
\text { lation. }\end{array}$ & Cow No. & $\begin{array}{c}\text { Titratable } \\
\text { acidity. }\end{array}$ & $\begin{array}{l}\text { Coagu- } \\
\text { lation. }\end{array}$ & Cow No. & $\begin{array}{c}\text { Titratable } \\
\text { acidity. }\end{array}$ & $\begin{array}{l}\text { Coagu- } \\
\text { lation. }\end{array}$ \\
\hline & $\begin{array}{l}\text { Lactic } \\
\text { acid. }\end{array}$ & & & $\begin{array}{l}\text { Lactic } \\
\text { acid. }\end{array}$ & & & $\begin{array}{l}\text { Lactic } \\
\text { acid. }\end{array}$ & \\
\hline & per cent & $\min$ & & per cent & $\min$. & & per cent & $\min$ \\
\hline 1 & 0.257 & $20-*$ & 1 & 0.241 & 6 & 31 & 0.203 & $4 \frac{1}{2}$ \\
\hline 2 & 0.235 & 3 & 2 & 0.231 & 11 & 2 & 0.193 & $20-$ \\
\hline 3 & 0.216 & $20-$ & 26 & 0.228 & 5 & 1 & 0.192 & $20-$ \\
\hline 4 & 0.214 & $20-$. & 31 & 0.222 & $5 \frac{1}{2}$ & 3 & 0.188 & $4 \frac{1}{2}$ \\
\hline 5 & 0.210 & 8 & 27 & 0.212 & 6 & 27 & 0.188 & $6 \frac{1}{2}$ \\
\hline 6 & 0.207 & $20-$ & 3 & 0.212 & $5 \frac{1}{2}$ & 6 & 0.188 & $20-$ \\
\hline 7 & 0.206 & 6 & 4 & 0.211 & $20-$ & 4 & 0.188 & $20-$ \\
\hline 28 & 0.201 & $20-$ & 5 & 0.205 & $5 \frac{1}{2}$ & 28 & 0.186 & $20-$ \\
\hline 9 & 0.200 & $20-$ & 9 & 0.197 & $20-$ & 12 & 0.184 & 10 \\
\hline 10 & 0.200 & $20-$ & 28 & 0.199 & $20-$ & 26 & 0.184 & 3 \\
\hline 11 & 0.195 & $4 \frac{1}{2}$ & 6 & 0.195 & $20-$ & 5 & 0.183 & $6 \frac{1}{2}$ \\
\hline 12 & 0.191 & $20-$ & 29 & 0.192 & $5 \frac{1}{2}$ & 9 & 0.182 & $20-$ \\
\hline 13 & 0.190 & $20-$ & 10 & 0.190 & $20-$ & 14 & 0.182 & 9 \\
\hline 14 & 0.189 & $6 \frac{1}{2}$ & 13 & 0.186 & 9 & 29 & 0.182 , & $1 \frac{3}{4}$ \\
\hline 15 & 0.182 & $20-$ & 12 & 0.185 & 11 & 11 & 0.178 & $3 \frac{1}{2}$ \\
\hline 16 & 0.179 & 4 & 11 & 0.184 & 5 & 13 & 0.175 & 4 \\
\hline 8 & 0.174 & 9 & 8 & 0.174 & $20-$ & 10 & 0.171 & $20-$ \\
\hline 17 & 0.172 & $20-$ & 14 & 0.175 & $6 \frac{1}{2}$ & 30 & 0.165 & $20-$ \\
\hline 18 & 0.167 & $20-$ & 15 & 0.172 & $20-$ & 15 & 0.163 & $20-$ \\
\hline 19 & 0.158 & 12 & 17 & 0.166 & $20-$ & 8 & 0.163 & $6 \frac{1}{2}$ \\
\hline 20 & 0.157 & $20-$ & 18 & 0.160 & $20-$ & 17 & 0.156 & $20-$ \\
\hline 21 & 0.156 & $20-$ & 30 & 0.162 & 4 & 18 & 0.154 & $20-$ \\
\hline 22 & 0.148 & 3 & 7 & 0.162 & 2 & 7 & 0.148 & 2 \\
\hline 23 & 0.146 & $3 \frac{1}{2}$ & 21 & 0.157 & $20-$ & 20 & 0.143 & $20-$ \\
\hline 24 & 0.143 & $20-$ & 20 & 0.147 & $20-$ & 19 & 0.135 & $20-$ \\
\hline \multirow[t]{5}{*}{25} & 0.120 & 2 & 23 & 0.145 & $5 \frac{1}{2}$ & 22 & 0.133 & 2 \\
\hline & & & 19 & 0.144 & $20-$ & 23 & 0.130 & 4 \\
\hline & & & 22 & 0.144 & 2 & 24 & 0.128 & $20-$ \\
\hline & & & 24 & 0.141 & 20 & 21 & 0.128 & $20-$ \\
\hline & & & 25 & 0.131 & $1 \frac{1}{2}$ & 25 & 0.102 & $1 \frac{1}{2}$ \\
\hline
\end{tabular}

${ }^{*} 20-=$ no coagulation in 20 minutes. 
lactic acid), it was of interest to know how much variation there was in the tritratable acidity of milk from individual cows, and what relation the acidity would bear to the coagulation. To study this, samples were taken from the University herd and titrated immediately, and the heat test in the xylene vapor bath applied as soon as possible. The results given in Table I were obtained.

The titratable acidity varies from 0.102 to 0.257 per cent. Out of the 86 samples, 45 are above 0.18 per cent.

In fresh milk there is no direct relation between titratable acidity and coagulation, as is evident from Table II. If fresh milk samples were more nearly alike in titratable acidity, then titratable acidity might bear a direct relationship to the heat

TABLE II.

Summary of Titratable Acidity and Coagulation.

\begin{tabular}{c|c|c|c|c|c}
\hline Date. & $\begin{array}{c}\text { No. of } \\
\text { samples. }\end{array}$ & $\begin{array}{c}\text { No. above } \\
\begin{array}{c}\text { s.18 per cent } \\
\text { acid.* }\end{array}\end{array}$ & $\begin{array}{c}\text { No. that are } \\
20+.+\end{array}$ & $\begin{array}{c}\text { No. below } \\
0.18 \text { per cent } \\
\text { acid. }\end{array}$ & $\begin{array}{c}\text { No. that are } \\
20+.\end{array}$ \\
\cline { 2 - 5 } May $\quad 8 \ldots \ldots \ldots$ & 26 & 15 & 5 & 11 & 6 \\
" $10 \ldots \ldots \ldots$ & 30 & 14 & 7 & 16 & 7 \\
" $16 \ldots \ldots \ldots$ & 30 & 16 & 11 & 14 & 6 \\
\hline Total......... & 86 & 45 & 23 & 41 & 19 \\
\hline
\end{tabular}

* Per cent above 0.18 per cent acidity, coagulating $20+=51.2$ per cent.

$\uparrow 20+$ means coagulation within 20 minutes.

$\ddagger$ Per cent below 0.18 per cent acidity, coagulating $20+=46.4$ per cent.

coagulation of commercial milk samples. The acidity would then be a measure of the amount of fermentation that had taken place. Lactic acid fermentation lowers the coagulating point in two ways; (1) it changes the reaction, and (2) it lowers the citric acid content of the milk very rapidly. ${ }^{2}$ Both of these are factors in lowering the coagulating point, as will be shown later.

Since fresh milk samples vary so widely in titratable acidity, it is impossible to measure the extent of acid fermentation in a sample by titration. For this reason it is impossible to use titratable acidity as a criterion of coagulability.

${ }^{2}$ Bosworth, A. W., and Prucha, M. J., Tech. Bull. 14, N. Y. Agric. Exp. Station, 1910. 
TABIE III.

Hydrogen Ion Concentration and Coagulation.

\begin{tabular}{|c|c|c|c|c|c|}
\hline \multicolumn{2}{|c|}{ Date. } & Cow. & $\mathrm{pH}$ & $\mathrm{C}_{\mathrm{H}}$ & $\begin{array}{l}\text { Coagulation in } \\
20 \text { min. }\end{array}$ \\
\hline \multicolumn{2}{|c|}{1919} & & & & \\
\hline \multirow{4}{*}{\multicolumn{2}{|c|}{ Feb. 21}} & 31 & 6.55 & $2.82 \times 10-7$ & $++t^{*}$ \\
\hline & & 32 & 6.83 & $1.48 \times 10^{-7}$ & \\
\hline & & 13 & 6.58 & $2.63 \times 10-7$ & +++ \\
\hline & & 24 & 6.83 & $1.48 \times 10^{-7}$ & - \\
\hline \multirow[t]{3}{*}{ “ } & 25 & 13 & 6.25 & $5.62 \times 10^{-7}$ & - \\
\hline & & 32 & 6.66 & $2.19 \times 10^{-7}$ & - \\
\hline & & 31 & 6.66 & $2.19 \times 10^{-7}$ & +++ \\
\hline \multirow[t]{5}{*}{ “ } & 26 & 13 & 6.58 & $2.63 \times 10^{-7}$ & +++ \\
\hline & & 32 & 6.69 & $2.04 \times 10^{-7}$ & $+t$ \\
\hline & & 31 & 6.70 & $1.99 \times 10^{-7}$ & $+t$ \\
\hline & & 24 & 6.73 & $1.86 \times 10^{-7}$ & \\
\hline & & 14 & 6.70 & $1.99 \times 10^{-7}$ & $+t+$ \\
\hline \multirow[t]{3}{*}{ “ } & 27 & 13 & 6.44 & $3.62 \times 10^{-7}$ & + \\
\hline & & 32 & 6.64 & $2.29 \times 10^{-7}$ & ++ \\
\hline & & 31 & 6.64 & $2.29 \times 10^{-7}$ & +++ \\
\hline \multirow[t]{3}{*}{ “ } & 27 & 24 & 6.70 & $1.99 \times 10^{-7}$ & - \\
\hline & & 14 & 6.44 & $3.62 \times 10^{-7}$ & - \\
\hline & & 33 & 6.59 & $2.56 \times 10^{-7}$ & $+t+$ \\
\hline \multirow[t]{6}{*}{ " } & 28 & 13 & 6.50 & $3.16 \times 10^{-7}$ & - \\
\hline & & 31 & 6.94 & $1.15 \times 10^{-7}$ & +++ \\
\hline & & 32 & 6.92 & $1.20 \times 10^{-7}$ & - \\
\hline & & 24 & 6.93 & $1.17 \times 10^{-}$ & ++ \\
\hline & & 14 & 6.50 & $3.16 \times 10^{-7}$ & - \\
\hline & & 33 & 6.68 & $2.09 \times 10^{-7}$ & $+t+$ \\
\hline \multirow[t]{3}{*}{ Mar. } & 3 & 13 & 6.67 & $2.14 \times 10^{-7}$ & - \\
\hline & & 31 & 6.84 & $1.44 \times 10^{-7}$ & - \\
\hline & & 33 & 6.69 & $2.04 \times 10^{-7}$ & ++ \\
\hline \multirow[t]{6}{*}{ “ } & 5 & 33 & 6.64 & $2.29 \times 10^{-7}$ & $+t+$ \\
\hline & & 13 & 6.64 & $2.29 \times 10^{-7}$ & - \\
\hline & & 31 & 6.93 & $1.17 \times 10-7$ & + \\
\hline & & 32 & 6.79 & $1.62 \times 10^{-7}$ & - \\
\hline & & 24 & 6.79 & 1. $62 \times 10^{-7}$ & - \\
\hline & & 14 & 6.58 & $2.63 \times 10^{-7}$ & - \\
\hline \multirow[t]{2}{*}{ " } & 6 & 24 & 6.97 & $1.07 \times 10^{-7}$ & \\
\hline & & $: 33$ & 6.59 & $2.57 \times 10^{-7}$ & +++ \\
\hline " & 7 & 31 & 6.85 & $1.41 \times 10^{-7}$ & +++ \\
\hline " & 10 & 33 & 6.79 & $1.62 \times 10^{-7}$ & +++ \\
\hline
\end{tabular}

* Number of plus signs indicates degree of firmness. 


\section{Hydrogen Ion Concentration.}

Titratable acidity does not give an index to true acidity, or hydrogen ion concentration, so that if there is any relation between acidity and coagulation, it would be most likely to exist between the hydrogen ion concentration and coagulation. To study this possibility the hydrogen ion concentration of fresh milk was determined by means of the gas chain method, and the heat test was applied by means of the autoclave. The results given in Table III were obtained.

From a study of the data it becomes evident that the hydrogen ion concentration is not the determining factor in the coagulation. Samples of equal $\mathrm{C}_{\text {н }}$ do not always respond alike to the heat test; one may remain liquid, and the other may form a firm coagulum. In a large number of cases samples of high $\mathrm{C}_{\mathbf{H}}$ did not coagulate, whereas samples of lower $\mathrm{C}_{\mathrm{H}}$ did, the exact reverse of what should happen if true acidity was the cause of the coagulation.

We must conclude from this that in fresh milk $\mathrm{C}_{\mathrm{H}}$ is not the determining factor in the coagulation. However, it may become a factor, for 'if we change the reaction of a milk sample by adding small amounts of acids the coagulating point is lowered.

\section{Concentration.}

The concentration of the milk would be expected to influence the coagulating point. This was found to be the case when milk was diluted (Table IV).

TABLE IV.

Relation of Coagulation to Concentration.

\begin{tabular}{c|c}
\hline 25 cc. of milk $+\mathrm{H}_{2} \mathrm{O}$. & Coagulation time. \\
\hline $\mathrm{H}_{2} \mathrm{O}$ added. & min. \\
\hline$c c$. & $1 \frac{1}{2}$ \\
0.0 & 2 \\
1.0 & $2 \frac{3}{4}$ \\
2.0 & 14 \\
3.0 & $35-$ \\
4.0 & $35-$ \\
5.0 & $35-$ \\
6.0 & \\
\hline
\end{tabular}


Not only the concentration of the casein influences the coagulating point, but also the concentration of the serum. This was determined by comparing the effect of water dilution to the effect of dilution with milk serum obtained by filtering the milk through Pasteur-Chamberlain filters (Table V).

In the dilution with water, where the casein and the serum are both diluted, the effect is greater than where the casein alone is diluted by adding serum; therefore, the concentration of the serum is also a factor influencing the coagulating point.

Concentration of casein and of serum may in part explain the, difference in the coagulating points of different milk samples.

TABLE V.

Relation of Coagulation to Concentration of Serum.

\begin{tabular}{c|c}
\hline 25 cc. of milk + serum. & Coagulation time. \\
\hline Serum added. & min. \\
\hline$c c$. & $1 \frac{1}{2}$ \\
0.0 & $1 \frac{3}{4}$ \\
0.1 & 2 \\
0.2 & Coagulation time. \\
\hline 25 cc. of milk $+\mathrm{H}_{2} \mathrm{O}$. & \\
\hline $\mathrm{H}_{2} \mathrm{O}$ added. & min. \\
\hline$c c$. & $1 \frac{1}{2}$ \\
0.0 & $2 \frac{1}{2}$ \\
0.1 & 4 \\
\hline 0.2 &
\end{tabular}

However, in most cases, with the slight variation in concentration, this factor is of minor importance, just as $\mathrm{C}_{\mathrm{H}}$ is. There must be another factor of greater importance.

\section{Composition and Balance of Milk Salts.}

Since electrolytes have a very marked effect upon the stability of colloids, we should expect that variations in the salt composition would influence the stability of the casein in the milk.

That the various salts exert an influence on the coagulating point was shown in a number of cases. 
The effect of an addition of ammonium oxalate to milk that previously coagulated is shown in Table VI.

The removal of calcium by precipitation prevents coagulation in most cases and similarly in most cases the addition of small amounts of calcium salts lowers the coagulating point. This coagulation can again be balanced by means of sodium citrate or dipotassium phosphate (Tables VII, VIII, IX, and X). Coagulation caused by $\mathrm{MgCl}_{2}$ or $\mathrm{BaCl}_{2}$ can also be balanced by sodium citrate (Tables XI and XII).

In most cases coagulation can be prevented by the addition of citrates or phosphates, the coagulation being due to an excess of calcium and magnesium. However, in a few cases the addition of citrates or phosphàtes did not prevent coagulation, but rather

TABLE VI.

Ammonium Oxalate Prevents Coagulation.

\begin{tabular}{c|c}
\hline 5 cc. of milk +10 per cent $\left(\mathrm{NH}_{4}\right)_{2} \mathrm{C}_{2} \mathrm{O}_{4}$. & Coagulation in 20 min. \\
\hline$\left(\mathrm{NH}_{4}\right)_{2} \mathrm{C}_{2} \mathrm{O}_{4}$ added. & \\
\hline drops & +++ \\
0 & ++ \\
1 & + \\
2 & - \\
4 & -- \\
\hline
\end{tabular}

hastened it. In these cases the addition of the proper amount of calcium salts prevents coagulation or at least raises the coagulating point (Tables XIII and XIV).

From the data we see that the calcium and magnesium are balanced by the phosphates and citrates of the milk practically in gram-equivalent amounts. The sodium and potassium chlorides in the concentrations present do not have any marked influence on the coagulating point, so that the balance of the four constituents, calcium, magnesium, citrates, and phosphates, largely determines whether a milk will coagulate or not. If calcium and magnesium are in excess, the milk will coagulate on heating. If calcium and magnesium are properly balanced with the phosphates and citrates, the optimum stability obtains. If phosphates and citrates are in excess, coagulation will also result. 
TABLE VII.

Balance between Calcium and Citrates.*

\begin{tabular}{c|c|c|c}
\hline \multicolumn{3}{c|}{$25 \mathrm{cc}$ of milk plus. } & \multirow{2}{*}{ Coagulation time. } \\
\cline { 1 - 2 } $\mathrm{M} / 2 \mathrm{Ca}$ acetate. & $\mathrm{M} / 2 \mathrm{Na}$ citrate. & $\mathrm{H}_{2} \mathrm{O}$ & \\
\hline$c c$. & $c c$. & $c c$. & $\min$. \\
0.0 & 0.0 & 1.3 & 3 \\
0.3 & 0.0 & 1.0 & $\frac{1}{2}$ \\
0.3 & 0.1 & 0.9 & $2 \frac{1}{2}$ \\
0.3 & 0.2 & 0.8 & 3 \\
0.3 & 0.3 & 0.7 & 2 \\
0.3 & 0.4 & 0.6 & $1 \frac{1}{2}$ \\
\hline
\end{tabular}

* The sodium citrate consisted of $25 \mathrm{cc}$. of sodium $\mathrm{M} / 2$ citrate plus 3 cc. of $\mathrm{m} / 2$ citric acid. This solution was distinctly acid, so that the balancing effect could not have been due to neutralization of acidity by means of the sodium citrate.

TABIE VIII.

Balance between Calcium and Citrates. ${ }^{*}$

\begin{tabular}{c|c|c|c}
\hline \multicolumn{3}{c|}{25 cc. of milk plus. } & \\
\cline { 1 - 2 } M/2 Ca acetate. & Corgulation time. & \\
\hline$c c$. & $c c$. & $\mathrm{H}_{2} \mathrm{O}$ & $\min$. \\
0.0 & 0.0 & $c c$. & 4 \\
0.4 & 0.0 & 1.6 & $\frac{1}{2}$ \\
0.4 & 0.2 & 1.2 & $40-$ \\
0.4 & 0.4 & 1.0 & $40-$ \\
0.4 & 0.6 & 0.8 & $2 \frac{1}{4}$ \\
0.4 & 0.8 & 0.6 & 2 \\
\hline
\end{tabular}

* The sodium citrate consisted of $25 \mathrm{cc}$. of $\mathbf{M} / 2$ sodium citrate plus 1 cc. of $\mathrm{M} / 2$ citric acid.

TABLE IX.

Balance between Calcium and Citrates.

\begin{tabular}{c|c|c|c}
\hline \multicolumn{3}{c|}{25 cc. of milk plus. } & \multirow{2}{*}{ Coaguiation time. } \\
\cline { 1 - 2 } $\mathrm{M} / 2 \mathrm{Ca}$ acetate. & $\mathrm{M} / 2 \mathrm{Na}$ citrate. & $\mathrm{H}_{2} \mathrm{O}$ & $\min$. \\
\hline$c c$. & $c c$. & $c c$. & $25-$ \\
0.0 & 0.0 & 1.8 & $\frac{1}{8}$ \\
0.8 & 0.0 & 1.0 & $\frac{1}{8}$ \\
0.8 & 0.4 & 0.6 & $25-$ \\
0.8 & 0.6 & 0.4 & $25-$ \\
0.8 & 0.8 & 0.2 & $4 \frac{1}{2}$ \\
0.8 & 1.0 & 0.0 & \\
\hline
\end{tabular}

THE JOURNAL OF BIOLOGICAL CHEMISTRY, VOL. $\mathbf{X}$, NO. 1 
TABLE X.

Balance between Calcium and Phosphates.

\begin{tabular}{c|c|c|c}
\hline \multicolumn{3}{c|}{$25 \mathrm{cc}$. of milk plus. } & \multirow{2}{*}{ Coagulation time. } \\
\hline s/2 Ca acetate. & $\mathrm{M}^{2} \mathrm{~K}_{2} \mathrm{HPO}_{4}$ & $\mathrm{H}_{2} \mathrm{O}$ & \\
\hline$c c$. & $c c$. & $c c$. & $\min$. \\
0.0 & 0.0 & 1.2 & $20-$ \\
0.5 & 0.0 & 0.7 & $\frac{1}{4}$ \\
0.5 & 0.2 & 0.5 & $\frac{3}{8}$ \\
0.5 & 0.3 & 0.4 & 1 \\
0.5 & 0.4 & 0.3 & $20-$ \\
0.5 & 0.5 & 0.2 & $20-$ \\
0.5 & 0.6 & 0.1 & 6 \\
0.5 & 0.7 & 0.0 & $20-$ \\
\hline
\end{tabular}

TABIE XI.

Balance between Magnesium and Citrates.

\begin{tabular}{c|c|c|c}
\hline \multicolumn{3}{c|}{$25 \mathrm{cc}$. of milk plus. } & \\
\hline $\mathrm{M} / 2 \mathrm{MgCl}_{2}$ & $\mathrm{M} / 2 \mathrm{Na}$ citrate. & $\mathrm{H}_{2} \mathrm{O}$ & Coagulation time. \\
\hline$c c$. & $c c$. & $c c$. & $\min$. \\
0.0 & 0.0 & 0.7 & $20-$ \\
0.3 & 0.0 & 0.4 & $\frac{1}{2}$ \\
0.3 & 0.2 & 0.2 & $20-$ \\
0.3 & 0.3 & 0.1 & $20-$ \\
0.3 & 0.4 & 0.0 & $\mathrm{~S}$ \\
\hline
\end{tabular}

TABLE XII.

Balance between Barium and Citrates.

\begin{tabular}{|c|c|c|c|}
\hline \multicolumn{3}{|c|}{$25 \mathrm{cc}$. of milk plus. } & \multirow{2}{*}{ Coagulation time. } \\
\hline $\mathrm{M} / 2 \mathrm{BaCl}_{2}$ & $M / 2$ Na citrate. & $\mathrm{H}_{2} \mathrm{O}$ & \\
\hline$c c$ & $c c$ & $c c$ & $\min$. \\
\hline $0: 0$ & 0.0 & 0.4 & $20-$ \\
\hline 0.2 & 0.0 & 0.2 & $\frac{1}{b}$ \\
\hline 0.2 & 0.2 & 0.0 & $20-$ \\
\hline
\end{tabular}

Thus the coagulation of a milk sample on heating may be due either to an excess or a deficiency of calcium and magnesium. We may axplain this in the following manner. The eascin of the milk is most stable with regard to heat coagulation when it is in combination with a definite amount of calcium. If the calcium 
combined with the casein is above or below this optimum, the casein is not in its most stable condition. The calcium in the milk distributes itsclf between the casein, citrates, and phosphates chiefly. If the milk is high in citrate and phosphate content, more calcium is necessary in order that the cascin may retain its optimum calcium content after competing with the citrates and phosphates. If the milk is high in calcium, there may not be

TABLE XIII.

A Sample in Which Calcium Provents Coagulation.

\begin{tabular}{c|c|c|c}
\hline \multicolumn{2}{c|}{25 cc. of milk plus. } & Coagulation time. \\
\hline $\mathrm{s} / 2 \mathrm{Ca}$ acetate. & $\mathrm{M} / 2 \mathrm{Na}$ citrate. & $\mathrm{H}_{2} \mathrm{O}$ & \\
\hline$c c$. & $c c$. & $c c$. & $\min$. \\
0.0 & 0.0 & 0.8 & $1 \frac{1}{2}$ \\
0.2 & 0.0 & 0.6 & $20-$ \\
0.2 & 0.1 & 0.5 & $1 \frac{1}{4}$ \\
0.2 & 0.2 & $0 .-1$ & 1 \\
0.2 & 0.3 & 0.3 & $\frac{3}{4}$ \\
0.2 & 0.4 & 0.2 & $\frac{3}{4}$ \\
\hline
\end{tabular}

TABLE XIV.

A Sample in Which Calcium Raises the Coagulating Point.

\begin{tabular}{|c|c|c|}
\hline \multicolumn{2}{|c|}{$25 \mathrm{cc}$. of milk plus. } & \multirow{2}{*}{ Coagulation time. } \\
\hline $\mathrm{M} / 4 \mathrm{Ca}$ acetate. & $\mathrm{H}_{2} \mathrm{O}$ & \\
\hline$c c$. & $c c$. & $\min$ \\
\hline 0.0 & 0.5 & $1 \frac{3}{4}$ \\
\hline 0.1 & 0.4 & 2 \\
\hline 0.2 & 0.3 & $2 \frac{1}{1}$ \\
\hline 0.3 & 0.2 & 3 \\
\hline 0.4 & 0.1 & 6 \\
\hline 0.5 & 0.0 & $22_{2}^{1}$ \\
\hline
\end{tabular}

sufficient citrate and phosphate to compete with the casein to lower its calcium content to the optimum. In such a case the addition of eitrates or phosphates makes the casein more stable by reducing its calcium content. The magnesium functions by replacing the calcium in the citrates and phosphates.

In most cases the coagulation is due to an excess of calcium and magnesium. It is possible to balance this excess by citrates, 


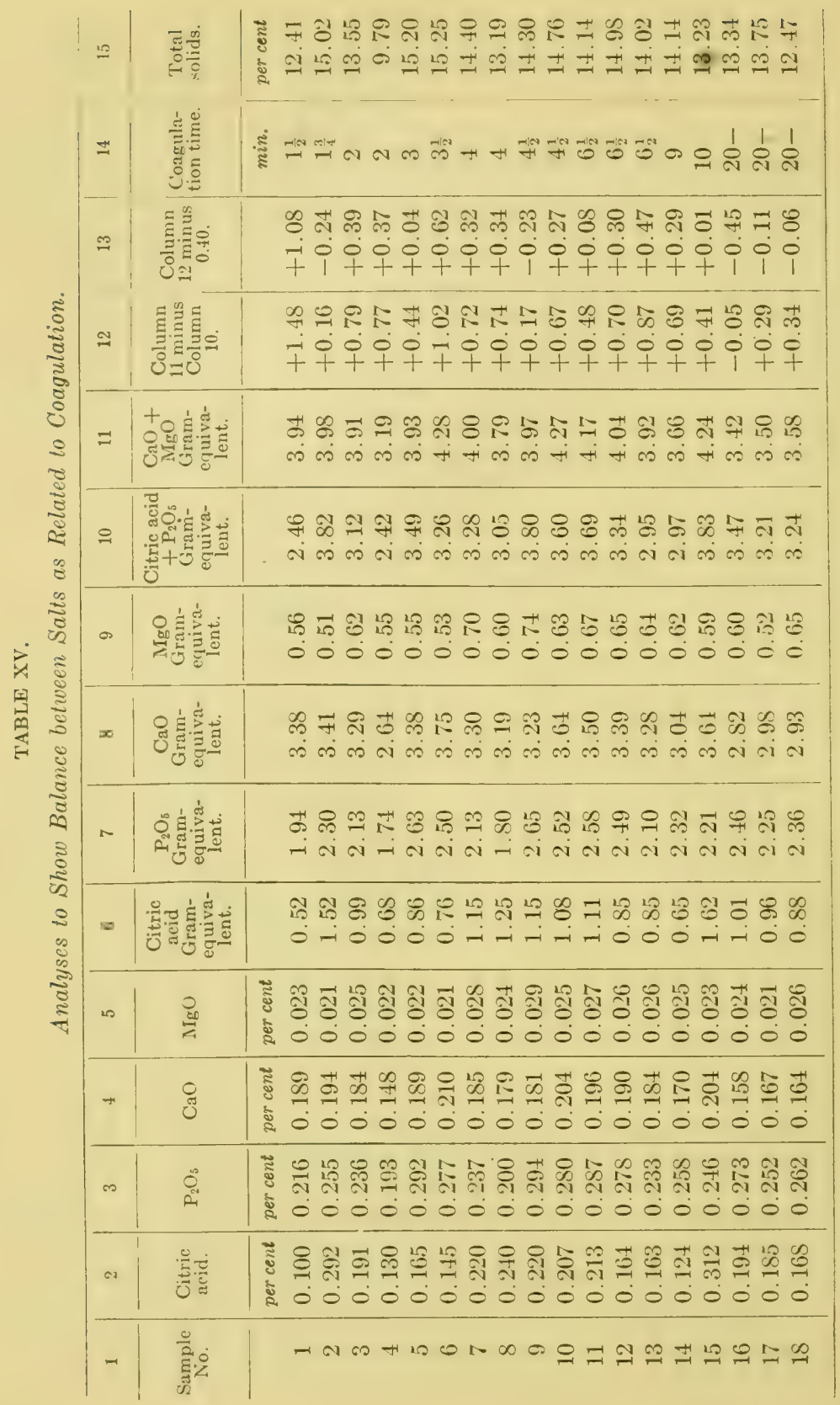




\section{H. H. Sommer and E. B. Hart}

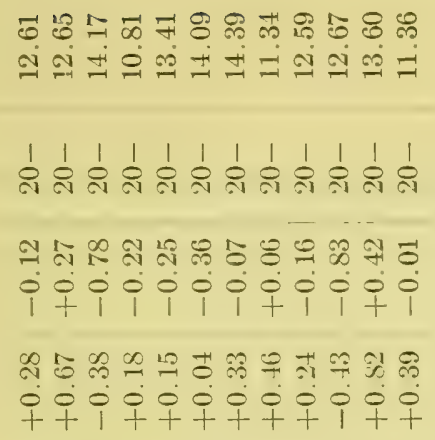

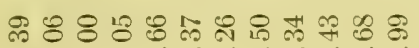

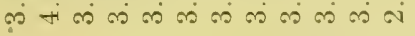

च का कर

นิธ 000000000000

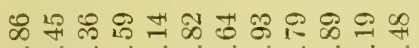
a ma a m a a a a na

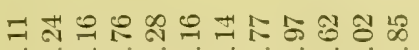

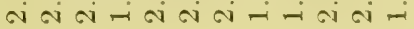

88 ผै -i-i-i-io-i-io

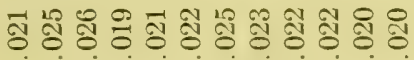
000000000000

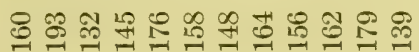
00 0000000000

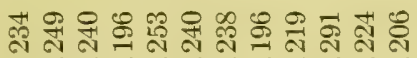
000000000000

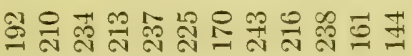
000000000000

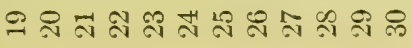


phosphates, carbonates, and other salts. It is also stated that danger of coagulation may be avo:ded in the actual practice of condensing milk by lengthening the "preheating" period, using higher temperatures. This may have the effect of lowering the soluble calcium content by precipitating part of it as insoluble calcium phosphate. ${ }^{1}$

To demonstrate the importance of the salt balance in the coagulation of milk, a number of samples were analyzed for total citric acid, phosphorus, calcium, and magnesium (Columns 2, 3, 4, and 5, Table XV). To calculate the balance between citric acid and phosphates, and calcium and magnesium the perecntages were converted into gram-equivalents as follows:

$$
\begin{aligned}
& \text { (a) } \frac{\text { Citric acid }}{192} \times 100 \\
& \text { (b) } \frac{\mathrm{P}_{2} \mathrm{O}_{5} \times 100}{71} \times \frac{7^{*}}{11} \\
& \text { (c) } \frac{\mathrm{CaO} \times 100}{56} \\
& \text { (d) } \frac{\mathrm{MgO} \times 100}{40}
\end{aligned}
$$

* Multiply by $\mathrm{T}_{1 \mathrm{~T}}$ because at $\mathrm{pH} 6.50$, the average reaction of milk, the ratio of primary to secondary phosphate, is such that the mean basicity of the phosphates is approximately $\frac{7}{11}$ of what it would be if all the phosphates were secondary phosphates.

Column 10 shows the sum of citric and phosphoric acids in gram-equivalents; Column 11, the sum of calcium and magnesium in gram-equivalents. Column 12 shows the balance; a plus sign showing an excess of calcium and magnesium, and a minus sign showing an excess of citric and phosphoric acids. In only a few cases is there an excess of citric and phosphoric acids, and the excess is small. Those that coagulated had the largest excess of calcium and magnesium. To make this result more apparent, Column 13 shows the values of Column 12 minus 0.40 . This figure was arbitrarily chosen and subtracted so as to make the coagulating samples have a plus sign and the non-coagulating samples have a minus sign. In five cases out of the thirty this result does not hold. However, the fact that, in twenty-five out of the thirty samples, those having the highest excess of calcium and magnesium 
over citrates and phosphates coagulated and those having the lowest excess did not coagulate, indicates that this factor is very important.

The five exceptions may be due to the other factors, concentration and reaction. Samples 2 and 9, with their small excesses of calcium and magnesium, should not coagulate; however, both samples are high in total solids. Samples 20 and 26 did not coagulate although the excess of calcium and magnesium is high; again the explanation may lie partly in the concentration of the milk, both samples being low in total solids. If the $\mathrm{pH}$ had been determined we might have gained further insight into these exceptions and an explanation for the irregularity of Sample 29.

SUMMARY AND CONCLUSIONS.

1. The main factor in the heat coagulation of fresh milk is the composition of the milk salts. Apparently casein requires a definite optimum calcium content for its maximum stability. The calcium content of casein is largely controlled by the magnesium, citrates, and phosphates present.

2. In fresh milk there is no relation between titratable acidity and heat coagulation.

3. Acid fermentation in milk lowers the coagulating point by changing the reaction and by lowering the citric acid content. However, the titratable acidity of fresh milk samples varies so widely that it is impossible to determine the extent of acid fermentation by titration. Therefore it is impossible to use the acidity of milk as a criterion of coagulability.

4. Difference in concentration accounts partly for the difference in coagulation of fresh milk samples.

5. Hydrogen ion concentration is not the determining factor in fresh milk coagulation. It is nevertheless a factor in fresh milks, and in commercial milks it may become an imbortant factor. 

